I know of but one paper treating synoptically of the North American species.

1882. Fuchs, Chas. Synopsis of the Lucanidx of the U. S. Bulletin Brooklyn Ento. Soc., V.

Capt. Thos. L. Casey has described a number of new species of Platycerus in various publications, but has not tabulated the genus.

\title{
A NEW SPECIES OF ASTEROSCOPUS.
}

BY JOIIN B. SMI'H, SC. D., RETGFRS COLLFGE, N. J.

Lederer characterizes Astcroscopus essentially as follows: Narrow-winged owlets, resembling Bombycids in the shaggy, loose vestiture. Palpi short, not exceeding the front, drooping. Tongue short and weak. Eyes naked, with bristly lashes. Antennæ comparatively long, with a tuft of hair at the base; in the male with short pectinations to the tip; in the female with sharp, ciliated angles to each joint. Thorax broad, convex, clothed with long, woolly hair. Abdomen shaggy, untufted. Body beneath and legs with dense woolly vestiture. Legs short, anterior tibia with a long claw at the tip.

The caterpillars are naked, considerably enlarged posteriorly, green, with a pale lateral stripe, and have an abrupt declivity or step on the last segment. They feed on various decidious trees, and when at rest elevate the anterior segments as do some of the Notodonts. They pupate underground and remain unchanged an unusualiy long time.

Heretofore no species properly referable to this genus has been clescribed from our fauna. The $A$. barometricus of Goossens, Le $N$ at. III., 380, is simply a redescription of Ufeus plicatus, Grt. Every structural character given by Goossens contradicts the description of the genus to which he refers his species and agrees with those of Lfeus.

A special properly referable to this genus was taken by $\mathrm{Mr}$. E. F. Heath, sent to Dr. Dyar for determination, and by him referred to me. I characterize it as follows:

Asteroscopus borfalis, $11, \mathrm{sp}$.

Ground colour a dark ashen gray, powdered with black, hairlike scales, which gives the insect a sordid, smoky appearance. Head and thorax perhaps a trifle darker than the wings, the head much retracted. Abdomen with somewhat finer vestiture, which show a tendency to a mouse-gray tint. Antennæ of the male yellowish-brown, distintcly but not lengthy pectina:ed, and with a tuft of creamy hair at the base. 
Primaries with all the veins black n arked, giving the insect a somewhat strigate appearance. No basal line. T. a. line a single, broad, diffuse, outwardly bent so as to form almost a right angle in the submedian interspace. T. p. line single, blackish, shortly dentate on the veins, starting from the costa over the reinform, bent outwardly far bevond the cell, then almost parallel with and rather close to the outer margin, to the inner margin. There is no s. t. line and there are no terminal dots; but the fringes are cut with triangular black dashes, the apices of which rest on the middle of the interspaces. There is a vague series of oval, darker sharles in the interspaces beyond the $t$. p. line. A median blackish shade starts obliquely from the middle of the costa, reaches the median vein at the bottom of the reinform, and is then discontinued. The reniform is large irregular, of the ground colour, outlined by a diffuse blackish line. Orbicular very long and narrow, decumbent, scarcely defined, reaching from the $t$. a line almost to the reniform. Claviform distinct, narrow, extending almost to the middle of the wing, outlined in diffuse blackish.

Secondaries, smoky over whitish, powdery, the apex and marg:n paler. Fringes whitish. Veins dusky. A series of blackish, somewhat undefined terminal spots in the interspaces. Discal spot of the under side showing through the wing.

Beneath, primaries smoky, powdery, shading to almost white toward the outer margin, which is marked by a broken terminal line and small, interspaceal black dots. The reniform appears here as a darker smoky shading, and the course of the t. p. line is marked by a cliffuse smoky shade which disappears before it reaches the inner margin. Secondaries white, shaded with smoky along the costal and inner margins Veins marked with blackish. A series of smoky terminal spots in the interspaces. A large blackish discal lunule, from which a black line extends to the base through the middle of the median cell.

Expands 2 inches $=5011111$.

Habitat: Cartwright, Manitoba.

A single male specimen, donated by Mr. Heath to the U. S. National Museum, where it is marked Type 4107 !

The species should be an easily recognizable one, not only from the generic characters, but from the distinct bombyciform appearance and the quite striking mactiation of the under side. The nearest approach to this occurs in Rancora, next to which the present genus and species may be placed in the series. 